\title{
THE EMPLOYER'S DUTY TO INDEMNIFY SHIPOWNERS FOR DAMAGES RECOVERED BY HARBOR WORKERS
}

\section{Lewis Weinstock $\dagger$}

For many years the topic of contribution and indemnity between joint-tortfeasors has attracted the attention of students of the law, and the discussion is still going on. ${ }^{1}$ During the past decade, however, the subject has attained special significance in connection with injuries to harbor workers; the expansion of responsibility of shipowners ${ }^{2}$ has produced a considerable body of decisions dealing with their attempts to shift the burden of damages to the worker's employer. Consequently, a re-examination of the doctrines of contribution and indemnity is in order to ascertain the manner in which they fit into the pattern of employer's liability which has developed from the enactment of the Longshoremen's and Harbor Workers' Compensation Act. ${ }^{3}$

$\dagger$ A.B. 1937, LL.B. 1940, University of Pennsylvania; member of the Philadelphia Bar. The views expressed in this Article are personal to the author and do not necessarily reflect those of his firm.

1. See, e.g., Davis, Indemnity Betzeen Negligent Tortfeasors: A Proposed Rationale, 37 Iowa L. REv. 517 (1952) ; Meriam and Thornton, Indemnity Between Tort-Feasors; An Evolving Doctrine in the New York Court of Appeals, 25 N.Y.U.L.Q. REv. 845 (1950); Hodges, Contribution and Indennity Among Tortfeasors, 26 TEx. I. Rev. 150 (1947). See also Leflar, Contribution and Indemnity Between Tortfeasors, 81 U. of PA. L. Rev, 130 (1932).

2. Prior to the decision by the Supreme Court in Seas Shipping Co. v. Sieracki, 328 U.S. 85 (1946), the duty of the shipowner to the harbor worker employed on board was the duty to furnish a safe place to work and to exercise due care. See id. at 103-08 (dissenting opinion). The limits of that responsibility were vastly expanded by the holding in Sieracki that the warranty by the shipowner that the vessel was "seaworthy," previously recognized as owed to cargo and crew, extends to the longshoremen and stevedores employed on board. This means that the duty of the shipowner now includes a species of liability without fault. This extension was characterized as "presenting to [harbor workers] . . . paid up accident insurance policies at the expense of a vessel by which they have not been employed." Id. at 107 (dissenting opinion); cf. Manich v. Southern S.S. Co., 321 U.S. 96 (1944). Its impact has since been accentuated by Petterson v. Alaska S.S. Co., 205 F.2d 478 (9th Cir. 1953), aff'd per curiam, 347 U.S. 396 (1954), which held that the warranty of seaworthiness by the shipowner extends even to gear furnished by employer. These new rules and the nature of the employer's activities have multiplied the number of cases in which the shipowner's liability is in whole or in part created by conduct of the employer; the natural result is an increase in the number of cases in which the shipowner is held liable to the harbor worker and seeks reimbursement from the employer.

A critical history of the developments in this field, including the latest cases, is given in Ambler, Seanen Are "Wards of the Admiralty" but Longshoremen Are Now More Privileged, 29 WAsh. L. Rev. 243 (1954); see also 102 U. of PA. L. REv. 402 (1954).

3. 44 STAT. 1424 (1927), as amended, 33 U.S.C. $\$ 901$ et seq. (1952), referred to throughout this Article as the "Act" or the "Statute." 
Section 5 of the Act ${ }^{4}$ provides that the compensation liability of an employer of harbor workers and longshoremen for injuries sustained in the course of their employment

"shall be exclusive and in place of all other liability of such employer to the employee, his legal representatives, husband or wife, parents, dependents, next of kin, and anyone otherwise entitled to recover damages from such employer at law or in admiralty on account of such injury . . . ."

Thus, the employer is protected by statute from tort suits by the employee. But the employee may be entitled to damages from the shipowner, in which event the question will arise as to whether the latter may have contribution or indemnity from the employer.

If the employee obtains a compensation award from his employer, the Act vests any cause of action against the shipowner in the employer, who then becomes entitled to bring and control the suit; if the suit results in a judgment, the employer recovers his compensation payments and expenses of suit and must remit the balance, if any, to the employee. ${ }^{5}$ If the suit remains in the hands of the employee, his employer is entitled to be reimbursed for compensation payments out of the recovery against the shipowner when the recovery exceeds the amount of compensation to which the employee is entitled; ${ }^{6}$ if no compensation has been paid and the judgment at least equals the amount of the compensation to which the employee is entitled, the employer is relieved of his compensation liability. ${ }^{7}$ In effect, therefore, a contribution or indemnity claim of the shipowner is to obtain reimbursement for damages he has paid which have in part or in whole inured to the benefit of the employer.

Of course, if there is no legal basis of liability of the shipowner to the employee in the first instance, ${ }^{8}$ no question of contribution or

4. 33 U.SC. $\$ 905$ (1952).

5. 33 U.S.C. $\$ 933(\mathrm{~b})-(\mathrm{e})(1952)$. In the cases discussed in this Article, suit was instituted by the employee. As a practical matter, relatively few compensation cases involve formal awards vesting the cause of action in the employer, since usually the employer's insurance carrier will promptly commence and continue payments to avoid the penalty provisions contained in $\$ 14(\mathrm{e}), 33$ U.S.C. $\$ 914$ (e) (1952). On the question of formal awards, see Grasso v. Lorentzen, 149 F.2d 127 (2d Cir.), cert. denied, 326 U.S. 743 (1945). 1943).

6. Section 33(a), 33 U.S.C. $\$ 933$ (a) (1952); The Etna, 138 F.2d 37 (3d Cir.

7. Section 33(a)-(f), 33 U.S.C. 933 (a)-(f) (1952). If the worker loses his suit against the shipowner, he can have compensation provided the employer has not been prejudiced. Chapman v. Hoage, 296 U.S. 526 (1936).

8. E.g., Firemen's Fund Indemnity Co. v. United States, 211 F.2d 773 (5th Cir. 1954), cert. denied, 23 U.S.L. WeER 3099 (Oct. 19, 1954); Spaulding v. Parry Navigation Co., 187 F.2d 257 (2d Cir. 1951), cert. denied sub nom. Parry Navigation Co. v. Todd Shipyards Corp., 342 U.S. 918 (1952). 
indemnity will arise. However, if the shipowner is liable to the employee, as for negligence or failure to furnish a safe place to work, or even liable without fault for breach of warranty of seaworthiness, ${ }^{9}$ there may be an accompanying fault ${ }^{10}$ on the part of the employer. There may be two causes which are concurrent; or they may be successive, in point of time, under circumstances which will call forth a judicial finding that one is "passive" as contrasted with the other which is "active"; they may be equal, or there may be a difference in degree so as to classify one as "primary" and the other "secondary." There may be a contract in effect between employer and shipowner which may provide the basis for a claim of indemnity founded on express or implied obligations arising thereunder. Under these varying circumstances, to what extent does the immunity of the statute protect the employer from such claims? Such is the question to be explored by this Article.

\section{Background for Indemnity: The Contribution Cases}

The cases applying the doctrine of indemnity to these situations must be read in the light of rules laid down in the contribution cases which, for the most part, preceded them.

The distinction between contribution and indemnity is not always clearly discernible. According to the Restatement of Restitution, it is that "Indemnity . . . means reimbursement of the total amount expended . . . [whereas] contribution means reimbursement of part of the amount expended." 12

The term "contribution" is used in this Article to refer to a claim for reimbursement by the shipowner on the theory that the shipowner and the employer are equally at fault, and that each should bear an equal portion of the loss. "Indemnity," on the other hand, is used in the sense of a claim asserted by the shipowner that, as between it and employer, the latter should bear the entire loss on a theory based on either comparison of fault as between the shipowner and employer, or on a duty arising from some relationship between them. In the former case, it is a strictly non-consensual duty; ${ }^{13}$ in the latter, it may arise

9. See discussion of Seas Shipping Co. v. Sieracki, 328 U.S. 85 (1946), supra note 2

10. The concept of "fault" or "negligence" by the employer; in this connection, is unsatisfactory, for the tort duty of the employer to the employee has been eliminated by statute. But the decisions make it impossible to avoid use of the term "negligence" or its equivalent; although the cases here discussed do not, for the most part, observe any distinction, the term should more accurately be used to describe that conduct which would constitute a breach of duty in the absence of statutory immunity. at 539

11. For a trenchant criticism of the "passive-active" test, see Davis, supra note 1,

12. Restatenent, Restitution c. 3, topic 3, at 331 (1937).

13. Leflar, supra note 1 , at 147. 
in consequence of a relationship to which the employer has consented, usually contract.

The trend in the earlier cases was toward allowance of contribution as between joint-tortfeasors, which is granted by admiralty law in collision cases. ${ }^{14}$ Thus, in Rederii v. Jarka Corp. (1939), ${ }^{15}$ where the issue arose on exceptions to a libel in admiralty, the shipowner claimed indemnity or contribution for damages which he had paid to the injured employee in compromise of a previous action. Without any discussion of the precise factual situation before it, the court held that Section 5 of the Act was not a bar to the libel, citing Westchester Lighting Co. v. Westchester County Small Estates Corp., ${ }^{16}$ which so held in a case involving a similar section of the New York compensation statute.

In The Tampico (1942) ${ }^{17}$ the injuries were caused by the defective condition of a barge and the concurring negligence of fellow-employees of the worker. In answering the shipowner's claim for contribution, the employer raised the defense of the Act, and argued that the claim was merely an indirect suit which, if brought directly by the employee against the employer, would be barred. The court rejected this defense on the ground that the right in admiralty to contribution between wrongdoers "does not stand on subrogation but arises directly from the tort." The court pointed to similar decisions in admiralty collision cases which held that, although under the Harter Act ${ }^{18}$ the owner of a seaworthy vessel was relieved of liability as to the cargo, such immunity does not protect the shipowner against a claim for contribution to damages which the other party to the collision was required to pay to the cargo owners.

However, when the contribution question was raised in Porello v. United States (1946), ${ }^{19}$ the Second Circuit had no difficulty in reaching the opposite conclusion. Here the employee was struck by a beam which fell for lack of a locking device and by reason of the negligence of a fellow-employee. The employee first accepted compensation under the Act, then elected to file a libel against the shipowner. In reversing the district court, ${ }^{20}$ although agreeing with its finding that

14. See Halcyon Lines v. Haenn Ship Ceiling \& Refitting Corp., 342 U.S. 282, 284 (1952). This situation is commonly referred to as a "both-to-blame" case: GRIFFIN, CollistoN \$245 (1949).

15. 26 F. Supp. 304 (D. Maine 1939).

16. 278 N.Y. 175,15 N.E.2d 567 (1938).

17. 45 F. Supp. 174 (W.D.N.Y. 1942).

18. 27 STAT. 445 (1893), 46 U.S.C. \$ 192 (1952). The analogy of the Harter Act was subsequently discussed fully and rejected in American Mut. Liab. Ins. Co. v. Matthews, 182 F.2d 322 (2d Cir. 1950).

19. 153 F.2d 605 (2d Cir. 1946).

20. The district court, in an unreported opinion, held that the owner of the vessel was negligent in not providing the locking device; the employer was chargeable with the negligence of its foreman in giving improper orders; the employee should have 
the shipowner and employer were concurrently negligent, the Second Circuit held that the statutory immunity was a complete defense from contribution claims against the employer:

"For a right of contribution to accrue between tort-feasors, they must be joint wrongdoers in the sense that their tort or torts have imposed a common liability upon them to the party injured. A. L. I. Restitution $\S 86 ; 13$ Am. Jur., Contribution $\S 51$. Since the libellant has no cause of action against his employer, the . . . [shipowner] can claim no contribution on the theory of a common liability which it has been compelled to pay." ${ }^{21}$

However, the court then went on to say that by reason of the express indemnity provision contained in the stevedoring contract the shipowner was entitled to full indemnity; and, in denying a petition for rehearing, the court stated that the contribution point "may be considered left open," since its determination was not essential to the decision as to indemnity under the contract in suit. ${ }^{22}$

The Supreme Court found the indemnity provision ambiguous, reversed the judgment, and remanded the case to the district court for determination of the meaning of the contract. ${ }^{23}$ The opinion of the Supreme Court ${ }^{24}$ clearly indicated that the indemnity question must turn on the meaning of the contract if applicable, and only if the contract were held not to apply would the Court be free to adjudge the responsibility of the parties under "applicable rules of admiralty law." 25

The views of the Second Circuit on the contribution point were not followed, when the question next arose in the Northern District of

judgment against the shipowner, who in turn was entitled to contribution from the employer as a joint-tortfeasor to the extent of half the damages, less the compensation payments received by the employee.

As to the allowance of such compensation payments, compare Pope \& Talbot, Inc. v. Hawn, 346 U.S. 406 (1953) ; see also, 67 HARv. L. REv. 884 (1954).

21. 153 F.2d 605, 607 (2d Cir. 1946).

22. Id. at 609 .

23. American Stevedores, Inc. v. Porello, 330 U.S. 446 (1947). In remanding the case, the Court suggested the possibility that evidence might be heard as to such meaning, and listed several possible meanings. See text at note 54 infra. On remand, the district court, noting the failure of either party to offer any evidence on the point, adhered to the previous decision of the circuit court that the shipowner was entitled to indemnity. 94 F. Supp. 952 (1950).

24. This was not, however, the issue which the Court regarded as the most important to be decided. As the shipowner was the United States Government, that issue was whether the Public Vessels Act of March 3, 1925, 43 STAT, 1112, 46 U.S.C. $\$ \$ 781$ et seq. (1952), permitted suits against the United States for damages on account of personal injuries, as well as property damages. The Court answered this question in the affirmative.

25. American Stevedores, Inc. v. Porello, 330 U.S. 446, 458 (1947). This portion of the opinion, intimating that contribution could be had in such a case, was expressly overruled in Halcyon Lines v. Haenn Ship Ceiling \& Refitting Corp., 342 U.S. 282, 284 n.5 (1952). 
California. In The S. S. Samovar (1947) ${ }^{26}$ the court rejected the defense of the statute ${ }^{27}$ to the claim of contribution and held that the statute "does not affect the conventional relationship between the employer and other tort-feasors." ${ }^{28}$ However, in Johnson v. United States (1948) ${ }^{29}$ another district court took a different view, and stated that to permit contribution would violate the basic principle of the compensation statute.

In American Mutual Liability Insurance Co. v. Matthews $(1950),{ }^{30}$ where the injury to the employee was caused by the breaking of a rope, the right of contribution was asserted on the theory that the shipowner and the employer were both negligent in that the shipowner supplied the defective rope and the employer was at fault in using it when the defect was patent. Although recognizing that most of the district court cases at that time had reached the opposite result, ${ }^{31}$ the Second Circuit adhered to its previous reasoning in the Porello case and held that the statute was a complete defense. Judge Learned Hand, in his concurring opinion, developed in some detail his views concerning the effect of the Act. Although he agreed that it "need not inevitably" be construed to bar the claim, he thought it should be so interpreted because

"it has imposed upon employers an absolute, though limited, liability, in exchange for a release from the preceding unlimited liability, conditional upon negligence. The release should, I submit, have the same scope as the imposed liability, which extends as

26. 72 F. Supp. 574 (N.D. Cal. 1947).

27. The statute was also held to be no defense to contribution claims in Portel v. United States, 85 F. Supp. 458 (S.D.N.Y. 1949); cf. Dubetz v. North American Shipping \& Trading Co., 1951 A.M.C. 492 (N.D. Cal.). In Barbarino v. Stanhope S.S. Co., 151 F.2d 553 (2d Cir. 1945), impleader of the employer was permitted without any mention of the Act.

28. The S.S. Samovar, 72 F. Supp. 574, 588 (N.D. Cal. 1947).

29. 79 F. Supp. 448 (D. Ore. 1948). Accord, Crawford v. Pope \& Talbot, Inc., 206 F.2d 784 (3d Cir. 1953); American Mut. Liab. Ins. Co. v. Matthews, 182 F.2d 322 (2d Cir. 1950); Baird v. John McShain, Inc., 108 F. Supp. 553 (D.D.C. 1952) ; Lundberg v. Prudential S.S. Corp., 102 F. Supp. 115 (S.D.N.Y. 1951) ; Miranda v. City of Galveston, 98 F. Supp. 245 (S.D. Tex. 1951) ; Liberty Mutual Ins. Co. v. Vallendingham, 94 F. Supp. 17 (D.D.C. 1950); Frusteri v. United States, 76 F. Supp. 667 (E.D.N.Y. 1947); Standard Wholesale Phosphate \& Acid Works, Inc. v. Rukert Terminal Corp., 193 Md. 20, 65 A.2d 304 (1949).

Calvino v. Pan-Atlantic S.S. Corp., 29 F. Supp. 1022 (S.D.N.Y. 1939), which is frequenty cited as in accord, dismissed a third-party complaint as outlawed under the Act since it sought to make the employer liable to the employee for any damages to which he might be entitled. The opinion does not mention the contribution point, but states that an amended complaint for indemnity would be permissible.

30. 182 F.2d 322 (2d Cir. 1950).

31. The decisions were based primarily on The Chattahoochee, 173 U.S. 540 (1899), construing the scope of exemption from liability under $\$ 3$ of the Harter Act; see text at note 18 supra. 
well to injuries caused by a joint wrong, as to those caused by the wrong of the employer alone." 32

Thus, when the Supreme Court was called upon to decide the question in Halcyon Lines v. Haenn Ship Ceiling \& Refitting Corp. (1952), ${ }^{33}$ all of the previous cases in the lower courts, although divided on the question whether contribution might be allowed, were unanimous in seeing the issue as one which turned on the meaning of the Act, and assumed that, absent the bar of the statute, the admiralty law provided the remedy of contribution as between joint-tortfeasors.

Curiously enough, the Supreme Court took a different view. It held that, while admiralty provided for equal sharing of damages and liability in collision cases, the Court had never expressly applied it to non-collision situations. Although, said the Court, it would feel free to do so "if wholly convinced that it would serve the best ends of justice," nevertheless it refused contribution on the ground that, in the absence of legislation, courts exercising a common-law jurisdiction have generally declined to allow contribution on their own initiative. It said that the solution of the problem should await congressional action because

"the legislative process is peculiarly adapted to determine which of the many possible solutions to this problem would be most beneficial in the long run." 34

The Court therefore found it "unnecessary" to decide the question presented by Section 5 of the Act. ${ }^{35}$

In Pope \& Talbot, Inc. v. Hawn (1953), ${ }^{36}$ the shipowner argued that the employee's damages included items which were to be refunded to the employer, ${ }^{37}$ and that the verdict for the employee against the shipowner should be reduced by the amount of such items. Otherwise, it was urged, the employer would receive "an unconscionable reward" although its negligence had contributed to the injury. 1950 ).

32. American Mut. Liab. Ins. Co. v. Matthews, 182 F.2d 322, 325 (2d Cir.

33. 342 U.S. 282 (1952), followed in Union Sulphur \& Oil Corp. v. W. J. Jones \& Sons, Inc., 195 F.2d 93 (9th Cir. 1952).

34. 342 U.S. at 286.

35. Both the district court, Baccile v. Halcyon Lines, 89 F. Supp. 765 (E.D. Pa. 1950) and the court of appeals, 187 F.2d 403 (3d Cir. 1951) treated the question solely from the standpoint of the Act, presumably on the assumption that the remedy was available in admiralty in such a case. The court of appeals granted contribution against the employer to the extent of its compensation liability, but held that the Act was a bar to the claim to the extent of the excess.

36. 346 U.S. 406 (1953).

37. See text at note 6 supra. 
From an equitable standpoint the argument seemed cogent enough. The answer of the Court, however, was that the Act expressly permits such recoupment by an employer, and to accept the contention by the shipowner would "frustrate this purpose to protect employers who are subject to absolute liability by the Act. Moreover, reduction of . . . [the shipowner's] liability at the expense of . . . [the employer] would be the substantial equivalent of contribution which we declined to require in the Halcyon case." 38 But in Halcyon the Court was being asked to give affirmative judgment against the employer, to make it assume an equal share of the damages to be paid to the employee, whereas in Hawn the argument merely sought to forestall recovery by the employer of its compensation expenses, a recovery which was tantamount to indemnity by the shipowner of the employer in a case of equal fault. The point is not here suggested by way of criticism; it is rather to demonstrate the length to which the Court went in adhering to the statute in the face of equitable considerations strongly persuasive toward a different result. And the degree of such adherence may be significant as evidence of the impact of the Act on both contribution and indemnity claims.

\section{INDEMNITy: The EQUity Background}

When we pass to a consideration of indemnity, it becomes essential to keep in view the distinction between claims for indemnity based on a contractual or other relation between indemnitor and indemnitee, and those which rest solely on a comparison of the nature or degree of their respective faults to the injured plaintiff. The distinction takes on a special significance because of the statutory immunity of the employer.

It will be recalled that Section 5 of the Act provides that the employer's obligation for compensation replaces "all other liability of such employer to the employee . . . and anyone otherwise entitled to recover damages from such employer . . . on account of such injury . . . ." We have seen that, although the Supreme Court has not yet spoken unequivocally on the point, the Second and Third Circuits and several district courts ${ }^{39}$ have held that this immunity extends to claims by the shipowner for contribution. If this is so, does the same reasoning require that it must likewise exclude claims for indemnity as well?

We begin with the assumption that, in the absence of the Act, the situation would call for application of the doctrine of indemnity on the

38. 346 U.S. at 412 .

39. See note 29 supra. 
same principles which govern the ordinary case of joint-tortfeasors: that a difference in the nature or degree of fault as between them may entitle one to shift the entire burden of loss to the other. ${ }^{40}$ Thus, in Standard Oil Co. v. Robins Dry Dock \& Repair Co., ${ }^{41}$ which grew out of an accident prior to the passage of the Act, the Second Circuit held that the shipowner could have indemnity from the employer, on the authority of Washington Gas Light Co. v. District of Columbia. ${ }^{42}$ In the latter case a municipal corporation had been held liable for injuries sustained by the plaintiff as a result of the negligence of the Gas Light Company, and the Supreme Court held that the municipality was entitled to be indemnified on the ground that, as between the company and the municipality, the former was chargeable with the "primary" fault. The Washington Gas Light rule is well established, and many decisions can be found where a similar result is reached on the basis of such distinctions as "primary" and "secondary," or "active" and "passive" fault. ${ }^{43}$

But obviously these cases assume an important element which is lacking here. They involve situations where both indemnitor and indemnitee are liable to the injured party. There, if the difference in degree or quality of fault is such as to move a court, in equity and good conscience, to view the putative indemnitor as the real villain; he should not be permitted to go free by the fortuitous circumstance that the plaintiff chose the other defendant as his target. It is a clear case of benefit conferred which calls for relief on a theory of quasi-contract.

If the putative indemnitor's liability to the injured party is abolished, the case takes on a different aspect. Assuming that the basis of the claim of indemnity rests on no more than a difference in degree or nature of fault, if the Act is held to constitute a bar to contribution claims, then indemnity in this sense must be in the same category, since it is, after all, for this purpose merely an "extreme form of contribution." 44 On the other hand, if the employer has breached an independent duty owed to the shipowner, as for example a contractual duty, the case may be viewed on a different footing. Inasmuch as the employer no longer owes any enforceable duty of due care to the employee, any discussion of the "fault" or "negligence" of the employer ${ }^{45}$ can be

40. See Davis, supra note 1 .

41. 32 F.2d 182 (2d Cir. 1929) ; accord, Seaboard Stevedoring Corp. v. Sagadahoc S.S. Co., 32 F.2d 886 (9th Cir. 1929).

42. 161 U.S. 316 (1896), which cited, at 327, as the "leading case," Lowell v. Boston \& Lowell R.R., 23 Pick. 24 (Mass. 1839).

43. Davis, supra note 1 , at $529,539-53$.

44. Slattery v. Marra Bros. Inc., 186 F.2d 134, 138 (2d Cir. 1951).

45. See note 10 supra. 
relevant only to the extent it bears upon the proper construction of his independent duty to the shipowner, which in this class of cases usually derives from the contractual relationship. Despite some false starts, and doubtful language, this approach has won acceptance in the latest cases.

\section{Effect of the Contribution Cases on Indemnity}

Our starting point must be where we stopped with the issue of contribution-the Halcyon case-in which it was held that the shipowner was not entitled to contribution. ${ }^{46}$ Primarily we are now interested in its significance on the question: To what extent does the holding apply to indemnity? It is interesting, but misleading, to observe that the reason stated by the Supreme Court for granting certiorari was

"because of the conflicting views taken by the circuits as to the existence of and the extent to which contribution can be obtained in cases such as this." 47

The two cases cited by the Court for the above statement are the decisions by the Second Circuit in American Mutual Liability Insurance Co. v. Mattheres, ${ }^{48}$ and that of the Ninth Circuit in United States v. Rothschild International Stevedoring Co. ${ }^{49}$ Presumably, this assumed a conflict between Mattheres and Rothschild in that the former denied contribution and the latter permitted it $A$ reading of the Rothschild opinion, however, clearly indicates that the Ninth Circuit regarded the case as one of indemnity, as distinct from contribution. Furthermore, the Mattheres case, in denying contribution to the shipowner, dealt with the question of indemnity and expressly recognized such a right ${ }^{50}$ in this type of case; it said merely that under the facts a claim for indemnity would be unjustified. If, therefore, the stated reason for certiorari means that the Supreme Court regarded contribution and indemnity as indistinguishable, it should follow that the effect of Halcyon would extend to both.

Yet, Halcyon has been universally interpreted otherwise, and, as we shall see, the decisions which have followed have been to the effect that it did not foreclose a claim of indemnity. While the Supreme

46. See discussion beginning in text at note 33 supra.

47. 342 U.S. at 283-84.

48. 182 F.2d 322 (2d Cir. 1950).

49. 183 F.2d 181 (9th Cir. 1950).

50. 182 F.2d at 323-24. 
Court has not yet spoken on this point, ${ }^{51}$ the question has been determined in a sufficient number of cases to establish a clear pattern. Also, the number of decisions is sufficient to afford some indication of the extent and limits of the doctrine in the present connection.

\section{Express Indemnity Clauses}

On one point, at least, there seems no room for doubt; if the claim is based upon an express contract to indemnify, the Act is not regarded as an obstacle.

Of course, express indemnity clauses may pose interpretation problems. ${ }^{52}$ In the Porello ${ }^{53}$ case, for example, the Supreme Court held that the phrasing of the indemnity clause was ambiguous, and remanded the case to the district court to make a finding with respect thereto. Three possible meanings of the indemnity clause were suggested; first, that the parties intended only that the employer should indemnify the shipowner for damages caused solely by the employer's negligence; second, that the employer should fully reimburse the shipowner for all damages caused in any part by the employer's negligence; or finally, that in the case of joint negligence the employer should be responsible for a share of the damages proportionate to its share of fault. ${ }^{54}$ It is clear throughout the Porello discussion, however, that the Court took for granted the enforceability of the promise.

51. It may do so, however, before the end of the present term, in the case of Palazzolo v. Pan-Atlantic S.S. Corp., 211 F.2d 277 (2d Cir. 1954), cert. granted sub nom. Ryan Stevedoring Co., Inc. v. Pan-Atlantic S.S. Corp., 23 U.S.L. WeEK 3092 (Oct. 14, 1954). See discussion of this case in text beginning at note 102 infra.

52. Where the contract contains an indemnity clause, which clearly provides for certain situations, and makes no reference to others, the case may be governed by the rule of expressio umim, even to the extent of implying the exclusion of all not expressed, even though all would have been implied had none been expressed. Southern Coast Corp. v. Sinclair Refining Co., 181 F.2d 960 (5th Cir. 1950); Potamkin and Plotka, Indemnification Against Tort Liability, 92 U. OF PA. L. REv. 347, 361 (1944). Cf. LoBue v. United States, 188 F.2d 800 (2d Cir. 1951). In the present situation, the writer believes that such a rule would be closest to what the parties actually intended, where the clause is clearly intended to denote the risks against which each party is to procure insurance. However, in Read v. United States, 201 F.2d 758, 763 (3d Cir. 1953), a clause which may be read as a mere statement of the applicable law was held not to be the "dispositive factor" in determining whether the duty to indemnify was an incident to the contract. See text beginning at note 94 infra. 23 supra.

53. American Stevedores, Inc. v. Porello, 330 U.S. 446 (1947). See text at note

54. Id. at 457-58. Cf. Potamkin and Plotka, supra note 52, at 350: "Thus we find that it is the intent of the parties that controls. But in the event of ambiguityand when was there ever held harmless language without such an event?-the courts magnanimously offer you a plethora of rules from which to choose your very own for your argument, always, however, reserving unto themselves a like store of wisdom from which to make their selections." 
In United States v. Arrow Stevedoring $\mathrm{Co}^{55}$ the Ninth Circuit held both that the promise to indemnify covered the claim in suit and that the Act did not take from the employer the right to contract for such a liability, even if it were assumed that in the absence of such contract the putative indemnitor was included within the protection of the Act. "We construe the Act as limited to liability of the employer to those entitled to damages from the injuries to or death of the employee, without any contract relationship to the employer other than the employment." ${ }^{56}$

Indeed, no case has been found in which any court has indicated that the Act would bar a claim based on express promise to indemnify. ${ }^{57}$ In such cases the problem, if any, is one of interpretation. However, as Porello demonstrates, that problem may be a formidable one; many cases dealing with such clauses in other fields show how difficult it can be. ${ }^{58}$

\section{Indemanty Not Based on Express Clauses in the Contract}

The absence of an express indemnity clause has, both before and after Halcyon, invariably been held not fatal. It is with the shaping of this branch of the law around the thrust of the statutory immunity into the midst of the pattern that we are primarily concerned. Yet it is here worth noting that the Statute does not prevent the parties from shifting the loss by their contracts inter sese.

\section{Cases Based on a Difference in Degree or Nature of Fault}

In Rich $v$. United States, ${ }^{59}$ the question of indemnity arose on the application by the shipowner to implead the employer under the 56th Rule in Admiralty. ${ }^{80}$ The lower court denied the impleader and was reversed; the Court of Appeals held that a petition alleging that an em-

55. 175 F.2d 329 (9th Cir. 1949).

56. $I d$. at 332 .

57. Such a clause was held to impose liability on the employer for full damages in Green v. War Shipping Administration, 66 F. Supp. 393 (E.D.N.Y. 1946), and in Severn v. United States, 69 F. Supp. 21 (S.D.N.Y. 1946). In LoBue v. United States, 188 F.2d 800 (2d Cir. 1951), and Palardy v. United States, 102 F. Supp. 534 (E.D. Pa. 1952), reliance on the indemnity clause failed because it was construed to go no farther than the scope of coverage provided in the standard form of workmen's compensation insurance policy, which was held not to extend to such a loss. The indemnity provision in Read v. United States, 201 F.2d 758 (3d Cir. 1953), is in a different category in that it was part of a contract between the shipowner and the general contractor, whereas it was the employee of a sub-contractor whose injuries were involved.

58. For collection of cases and discussion, see Potamkin and Plotka, supra note 52 , at 349 .

59. 177 F.2d 688 (2d Cir. 1949).

60. 28 U.S.C. Admiralty Rule 58 (1950). 
ployer may be partly or wholly liable by way of indemnity was not barred by the Statute, since, if it should turn out that the injuries were "primarily" caused by the negligence of the employer, the shipowner:

"would have a cause of action against the employer based upon the latter's independent duty to indemnify it for any loss sustained by the libellant's election to sue for injuries." 61

The opinion did not discuss the source of that duty, and the existence of a contract was not mentioned. The primary authority cited was the decision by the New York State Court of Appeals in Westchester Lighting Co. v. Westchester County Small Estates Corp. ${ }^{62}$ In that case the death of the employee was attributed to negligence of the employer which caused the breaking of a gas pipe on the premises of the property owner. Having paid damages for the death, the landowner brought an action against the employer for indemnity. The defense was that employer had secured compensation to its employees under the New York compensation statute which conferred immunity on the employer in terms identical with those contained in the Longshoremen's Act. This defense was rejected, and the court held that recovery over

"need not be rested upon any theory of subrogation. An independent duty or obligation owed by the employer to the third party is a sufficient basis for the action." es

The "independent duty" here referred to may have been a tort duty, ${ }^{64}$ i.e., the duty of the employer to use due care for the protection of the property of the indemnitee. Since the employer's negligence had caused the breaking of the pipe, and that break had produced the injury, the damages paid by the indemnitee were presumably part of the foreseeable consequences.

In United States v. Rothschild International Stevedoring Co. ${ }^{65}$ the injury was caused by a defective winch. The defect had occurred twice before and had been reported to the shipowner, and the employer had actual knowledge of the defect. In granting indemnity, the court based its result on the fact that, although both the shipowner and the employer were negligent, the negligence of the former had been com-

61. Rich v. United States, 177 F.2d 688, 691 (2d Cir. 1949).

62. 278 N.Y. 175,15 N.E.2d 567 (1938).

63. Id. at 180,15 N.E.2d at 569 .

64. This duty has been variously described as based on contract (American Mut. Liab. Ins. Co. v. Matthews, 182 F.2d 322 (2d Cir. 1950)) and as tort (Slattery v. Marra Bros., 186 F.2d 134 (2d Cir. 1951)). It may of course have been either; the opinion is not clear in this regard.

65. 183 F.2d 181 (9th Cir. 1950). 
pleted and that of the employer, in permitting the employee to work under the circumstances, was an "independent act of negligence, which supervenes in time, and which has as its basis a condition which has resulted from this first act of negligence . . .; but in that case we say that the consequences of the first act of negligence did not include the consequences of the second." ${ }^{68}$ The court went on to cite the Restatement of Torts, ${ }^{67}$ distinguishing between "passive" and "active" negligence.

The opinion does not discuss any contract between the shipowner and the stevedore, nor is there any explanation of the resort to rules of proximate cause as the sole basis of liability. Proximate cause, said the court, was the "sole question." 68

There are other opinions in which the discussion has proceeded as though the sole determinant in the case were the difference in nature or degree of fault of shipowner and employer. Thus, in Shannon $v$. United States ${ }^{69}$ the court, although citing as its authority the Mattheres case, ${ }^{70}$ reasoned in terms of the "active" negligence of the shipowner and the "passive" fault of the employer to justify its denial of indemnity. And in Babnick v. The Mt. Athos ${ }^{71}$ the court held the employer liable for indemnity on the ground that its "negligence" was the "sole, proximate, active and moving cause of the accident. . . ." 72

At first glance the discussion in terms of proximate cause may seem inapt. Of course, the shipowner could not be liable in the first instance to the employee, and there would be no subject of a claim for indemnity, unless, as against the injured workman, some breach of duty by the shipowner were held to be the proximate cause of the accident.

Yet, what is meant by such references to causation can better be understood in the context of cases of quasi-contract indemnity where the result has been rationalized in such terms. In Nashua Iron \& Steel Co. v. Worcester \& N.R.R., ${ }^{73}$ one $C$ had been injured when he was run over by the plaintiff's horse. In a prior suit, $C$ had recovered for his injuries from the owner of the horse on the ground of

66. Id. at 182, quoting from The Mars, 9 F.2d 183, 184 (S.D.N.Y. 1914).

67. Restatement, ToRTs $\$ 441$ and comment 2 (1934).

68. 183 F.2d at 182. Perhaps it is significant that the shipowner was the United States; it seems fair to assume that a contract existed between the parties which gave rise to the duty to indemnify, see Slattery v. Marra Bros., 186 F.2d 134, 139 (2d Cir. 1951), and which was such as to narrow the issue of the question of re sponsibility to proximate cause, see Comparison of Fault and the Contractual Theory of Recoz'ery, infra at p. 342.

69. 119 F. Supp. 706 (S.D.N.Y. 1953). See Coates v. Potomac Electric Power Co., 95 F. Supp. 779, 783 (D.D.C. 1951).

70. American Mut. Liab. Ins. Co. v. Matthews, 182 F.2d 322 (2d Cir. 1950).

71. 122 F. Supp. 68 (W.D. Wash. 1954).

72. Id. at 73 .

73. 62 N.H. 159 (1882). 
negligence. The owner was now suing defendant for indemnity on the ground defendant had frightened the horse. The court assumed, on defendant's demurrer, that, while plaintiff had been guilty of negligent mismanagement so far as $C$ was concerned, defendant had a later chance to avoid frightening the horse, and sustained the complaint on the basis of the last clear chance doctrine. If, said the court, the owner could have recovered from defendant for injury to the horse, he might also have as damages the loss he suffered by reason of $C^{\prime} s$ action against him. That is to say, if the doctrine is applicable, it will govern the result whether the plaintiff's injury is to his horse or to his pocketbook, and the question of causation is determined by the same principles as in a tort suit, even though the theory of recovery is quasi-contract.

There is a considerable body of cases in the quasi-contract field where indemnity is awarded on the rationale of such terms as "sole," "active," "proximate," or "primary" cause; "nonfeasance" versus "misfeasance"; whether the parties are in pari delicto, and so forth. ${ }^{74}$ Usually they involve facts in which there is a difference in time of occurrence between the conduct of the would-be indemnitee and indemnitor. In some cases the "active" negligence came after the "passive" misconduct; in others, the reverse occurred, and the "passive" negligence consists in failure to discover and remedy the dangerous situation created by the "active" negligence. While the type of reasoning employed in such cases is generally unsatisfactory, they have long constituted a settled body of decisions in the field of quasi-contractual indemnity. It is therefore hardly surprising to find the courts borrowing their language where injuries to a harbor worker may be traced to acts or omissions by both shipowner and employer.

But, as we have seen, the basic condition of quasi-contractual liability, that both persons are liable to the injured party, is eliminated by the bar of the Statute, and to apply the Washington Gas Light rule without more is to ignore an insurmountable obstacle to the result. ${ }^{75}$ Perhaps the true significance of these cases can be understood after further examination of the duty between shipowner and employer.

74. Leflar, supra note 1 , at 151 et seq.

75. Cf. Barber S.S. Lines, Inc. v. Quinn Bros. Inc., 104 F. Supp. 78 (D. Mass. 1952). After pointing out that the basis of the suit for indemnity was for breach of "an implied term of [plaintiff's] contract with defendant," the court upheld the claim as "a matter of implied contract," for which "the owner is entitled to restitution." Id. at 80 . For this proposition, the court cited REstatensent, RestrTution $\$ 95$ (1937) and various cases, including Washington Gas Light Co. v. District of Columbia, 161 U.S. 316 (1896).

Since the indemnitor was not the employer, the Act was not involved, and the result could rest on either contract or quasi-contract. It is worth noting that the cited RESTATENENT section embraces the latter; where liability is based on a breach of contractual or relational duty, such liability is outside the field intended to be covered by this section: Restatement, REstrtution c. 3, topic 3, introductory note, at 330 . 


\section{Cases Based on a Contractual Relationship}

Between Rich and Rothschild there had appeared the Second Circuit decision in Matthezes. ${ }^{76}$ That opinion, it now seems, deserves note as the first helpful discussion on the question here involved. To appreciate its significance on the indemnity point, we should first observe that in the usual case the contract between the shipowner and employer provides that the latter shall service or repair the ship, or perform stevedoring or other services to and about the vessel. This may involve various incidental activities by the employer related to the work, such as supplying loading equipment and furnishing lights. The agreement may contain an express provision that the lights shall be "adequate," or that the work shall be "properly" performed. In the absence of such expressions, normally they would be implied. ${ }^{77}$ If the employer's activities in performing such a contract have resulted in injury to a third person under circumstances which the employer knows may result in a successful suit against the shipowner, the question will be presented as to whether the shipowner's loss will constitute damage for breach of contract by the employer, express or implied, to do the work properly.

Such a result would seem easily supported by resort to familiar principles of the law of contract, or at most a simple extension thereof. Thus, Section 334 of the Restatement of Contracts is to this effect:

"If a breach of contract is the cause of litigation between the plaintiff and third parties that the defendant had reason to foresee when the contract was made, the plaintiff's reasonable expenditures in such litigation are included in estimating his damages."

Illustration 5 to this section holds a supplier of defective equipment liable to the employer for breach of contract where the defect causes injuries to an employee to whom the employer was compelled to pay damages. ${ }^{78}$ By the same token, if employer $A$ contracts to provide adequate lights in connection with stevedoring' services to shipowner $B$, and fails to do so, resulting in injury to $C$ for which $B$ is liable, $B$ 's consequential loss is part of $B^{\prime} s$ damages for breach of contract by $A .^{\mathbf{7 9}}$ This is merely an application of the general contract rule that, provided the damages in question were foreseeable, ${ }^{80}$ the contractor must

76. American Mut. Liab. Ins. Co. v. Matthews, 182 F.2d 322 (2d Cir. 1950).

77. Lundberg v. Prudential S.S. Corp., 102 F. Supp. 115 (S.D.N.Y. 1951).

78. The illustration is Mowbray v. Merryweather, [1895] 2 Q.B. 640 (C.A.).

79. Crawford v. Pope \& Talbot, Inc., 206 F.2d 784 (3d Cir. 1953), discussed in text at note 92 infra.

80. Restatearent, Contracts $\$ 330$ (1932). 
reimburse the owner for all damages which "naturally" ensued, including damages which the owner is required to pay to a third party, in consequence of the breach. ${ }^{81}$

The injuries in Matthews were caused by a defect in a rope supplied by the shipowner. The defect was patent, and the fault asserted to be chargeable to the employer was the failure to discover it. Although the claim was for contribution, in denying contribution the court relied upon indemnity cases and rested the result squarely on the effect of the contractual relationship between the parties:

"By contract an employer may become bound to indemnify his promisee against liability resulting from improper performance of the work undertaken by the employer. Such a case is Westchester Lighting Co. v. Westchester Estates, 278 N. Y. 175, 15 N. E. 2d 567, involving the New York Workmen's Compensation Act, Consol. Laws, c. 77, upon which the Longshoremen's and Harbor Workers' Act was modeled. There an employee of the contractor was killed by gas escaping from a pipe which the contractor was engaged to repair upon the premises of Westchester Estates. The decedent's widow having recovered a judgment against the land owner, the latter sued the employer for indemnity and the employer pleaded that a provision of the state statute almost identical with 33 U. S. C. A. § 905 exempted it from tort liability to the widow. But the court held that the plaintiff could recover, not by virtue of the widow's right but on the employer's promise to do the work properly. A similar decision under the Longshoremen's Act is Rich v. United States, 2 Cir., 177 F. 2d 688. In both of those cases, the primary cause of injury to the employee was breach of a contractual duty owed to the promisee to do the work properly. In the case at bar no promise by the employer can be implied that he will not use equipment furnished him by the shipowner to be used for the very purpose to which it was put. Nor can a promise be implied that he will use care to detect any defect in the equipment which patently existed when the equipment was delivered for use by the employer. To imply such a promise would mean that the employer agreed to protect the shipowner against liability arising out of the shipowner's own negligence. In the absence of an express promise, such an implication would be utterly unreasonable. Hence we can find no contractual basis for indemnity ${ }^{82}$ or contribution. To impose a noncontractual duty of contribution on the employer is pro tanto to deprive him of the immunity which the statute grants him in

81. Bethlehem Shipbuilding Corp. v. Joseph Gutradt Co., 10 F.2d 769 (9th Cir. 1926).

82. Followed and applied: Mikkelsen v. The Granville, 101 F. Supp. 566 (E.D.N.Y. 1951), aff'd per curiam, 191 F.2d 858, rehearing denied, 192 F.2d 809 (2d Cir. 1951). See also, Standard Wholesale Phosphate \& Acid Works, Inc. v. Rukert Terminal Corp., 193 Md. 20, 65 A.2d 304 (1949). 
exchange for his absolute, though limited, liability to secure compensation to his employees." 83

It happens that neither of the opinions the court here cited, Westchester and Rich, made any reference to a contract which would of itself justify this explanation of their significance. ${ }^{84}$ Nevertheless, in retrospect, the rationale adopted in the Matthews case seems inevitable.

It only remained for Judge Learned Hand to summarize in his usual masterly fashion the issues and the proper rules by which they are governed. In Slattery $v$. Marra Bros. ${ }^{85}$ the dispute originated in a suit by the employee against Marra for personal injuries resulting from the latter's negligent maintenance of a door upon the pier on which the employee was working. The accident occurred when the injured employee and other members of a gang of stevedores were raising the door in question and dropped it to the floor, pinning his leg. It is important to note that Marra was the lessee of the pier and had no contractual relationship with the employer. Marra filed a third-party complaint against the employer, demanding indemnification for any damages that the employee might recover. Although the case involved provisions of the New Jersey Workmen's Compensation Act, it has won wide acceptance in cases arising under the Longshoremen's Act. The relevant portion of the New Jersey statute gave to workmen's compensation the effect of "a surrender by the parties [employer and employee] of their rights to any other method, form or amount of compensation." 86

After holding that the plaintiff was entitled to recovery from Marra for negligence, Judge Hand proceeded to discuss the claim for indemnity by Marra against the employer based upon the negligence of the latter's employees in raising the door. He pointed out that, since the New Jersey Act provided that the employee's contract of employment was a "surrender" of any other right against his employer, the latter was under no liability to him of any kind other than his right to compensation. Therefore, Marra's right to indemnity "cannot rest upon any liability of. . . . [the employer] to . . . [the employee]; and, if it exists at all, it is hard to see how it can arise in the absence of some legal transaction between . . . [Marra and the employer]

83. American Mut. Liab. Ins. Co. v. Matthews, 182 F.2d 322, 323-24 (2d Cir. 1950) (italics added).

84. In Slattery v. Marra Bros., Inc., 186 F.2d 134 (2d Cir. 1951), Judge Hand's opinion recognized that the result in Westchester could also rest on a tort relationship as between indemnitor and indemnitee. See quotation from Slattery in text at note 88 infra.

85. 186 F.2d 134 (2d Cir. 1950).

86. N.J. Stat. ANN. §34:15-8 (Cum. Supp. 1953). 
other than that of joint tortfeasors: such as contract-as was the case in Burris v. American Chicle Co., 2 Cir., 120 F. 2d 218, and Rich v. United States, 2 Cir. 177 F. $2 \mathrm{~d} 688$-or as tort-as was the case in Westchester Lighting Co. v. Westchester Estates Corp., 278 N. Y. 175, 15 N. E. 2d 567." 87

Judge Hand went on to note that, in the absence of a compensation act, courts have at times based indemnity merely upon a difference between the kinds of negligence of the two tortfeasors. "Such cases may perhaps be accounted for as lenient exceptions to the doctrine that there can be no contribution between joint tortfeasors, for indemnity is only an extreme form of contribution. When both are liable to the same person for a single joint wrong, and contribution, stricti juris, is impossible, the temptation is strong, if the faults differ greatly in gravity, to throw the whole loss upon the more guilty of the two." 88 Judge Hand then proceeded to discuss the New Jersey law. Assuming, he said, that where both tortfeasors are liable to the injured person, it is the law that, regardless of any other relation, the difference in gravity of the faults of joint-tortfeasors may be great enough to throw the entire loss upon one:

"We cannot, however, agree that that result is rationally possible except upon the assumption that both parties are liable to the same person for the joint wrong. If so, when one of the two is not so liable, the right of the other to indemnity must be found in rights and liabilities arising out of some other legal transaction between the two. However, in the case at bar, not only was the . . . [employer] not liable to . . . [the employee], but it had no contract with Marra Bros., Inc., or any other legal relation with it except that of joint tortfeasor. Unless therefore there be some controlling authority to the contrary, the amended complaint was rightly dismissed.

"There is no such authority: none whatever in New Jersey, and none outside to which we think its courts would feel bound to yield. In American Mutual Liability Ins. Co. v. Matthews, 2 Cir. 182 F. $2 \mathrm{~d} 322$, we held that a shipowner, who had been held liable to a longshoreman for defect of the ship's tackle, should not have contribution against the longshoreman's employer because of the employer's negligence in performing a stevedoring contract with the shipowner. We so decided because we held that it was not a breach of the employer's contract for him to use defective tackle supplied by the shipowner; and it was only upon a breach of contract that the shipowner could rely. The decision of the Ninth Circuit in United States v. Rothschild International Stevedoring Co., 183 F. 2d 181, can indeed hardly be reconciled with ours,

87. Slattery v. Marra Bros. Inc., 186 F.2d 134, 138 (2d Cir. 1950).

88. Ibid. 
for we can see no more reason to hold that it was a breach of the stevedore's contract with the ship to use a winch known to be defective than to use a defective stay. However, it is not clear that the decision did not presuppose that the stevedore failed in the performance of its contract.with the ship; in which event the only difference between us is in the interpretation of such a contract. In any event it is not certain that the result would have been the same, had there been no contract whatever between the two. . . . Westchester Lighting Co. v. Westchester Estates Corp. can also rest upon the tort which the indemnitor committed against the indemnitee. So far as we can see therefore there is nobody [sic] of sure authority for saying that differences in the degrees of fault between two tortfeasors will without more strip one of them, if he is an employer, of the protection of a compensation act; and we are at a loss to see any tenable principle which can support such a result."

After Matthews and Slattery, with rare exceptions, ${ }^{90}$ the opinions as we shall presently see have generally recognized the contractual theory of indemnity in these cases. ${ }^{91}$

From three recent decisions it is clear that the Third Circuit has adopted this theory. In Craveford v. Pope \& Talbot, Inc., ${ }^{92}$ where the injuries were caused by the employer's failure to furnish adequate lights, the court rejected the argument that Halcyon barred claims for indemnity, as distinct from contribution, and held that the right to indemnity may "arise by virtue of an express contract or such a right may be raised from the circumstances surrounding the contractual relationship between the employer and the third party. In either case the indemnitee has a claim which is independent of and does not derive from the injury to the employee, except in a remote sense not within the provisions of Section 5." 93

The contractual nature of the shipowner's claim had previously been pointed up by the same court in Read $v$. United States. ${ }^{94}$ There indemnity was sought by the shipowner from the prime contractor for damages recovered by an employee of a sub-contractor; hence no question as to the effect of the Act was involved. The contract between

89. Id. at 139 (italics added).

90. Shannon v. United States, 119 F. Supp. 706 (S.D.N.Y. 1953) ; Babnick v. The Mount Athos, 122 F. Supp. 68 (W.D. Wash. 1954). See text at notes 69, 71 supra.

91. In addition to the cases to be discussed in the text, see Lukasiewicz v. Moore-McCormack Lines, Inc., 104 F. Supp. 572 (E.D.N.Y. 1952). The contractual theory was recently applied and followed in a case arising under a state statute: Peak Drilling Co. v. Halliburton Oil Well Cementing Co., 215 F.2d 368 (10th Cir. 1954).

92. 206 F.2d 784 (3d Cir. 1953).

93. Id. at 792 .

94. 201 F.2d 758 (3d Cir. 1953). 
the owner and contractor included an express indemnity provision. Thus, two alternative theories of recovery were available-express promise to indemnify, and quasi-contract. But the contractor was insolvent, and the precise basis of indemnity became important in determining whether the liability to the shipowner would be covered by the contractor's liability insurance policy. ${ }^{95}$ On behalf of the shipowner it was argued that indemnity "by operation of law" should be granted; whereas the insurer urged that the sole basis for indemnity was the express assumption of liability in the contract, an argument which, if sustained, would relieve the insurer ${ }^{96}$ Subscribing to neither of these contentions the court held: that the contractor had breached its contractual duty to provide adequate lighting and for that reason alone was liable to indemnify the shipowner; that this duty existed independently of any express indemnity promise, and it was immaterial that such a promise had been included. ${ }^{97}$

If there was any doubt regarding the position of the Third Circuit, none existed after Browen v. American-Hawaiian S.S. Co. ${ }^{98}$ There it was argued that a right of indemnity exists where the liability of the shipowner is "secondary" or "passive," as compared to that of the employer, which is "primary" or "active," and that the duty did not depend solely on a contract between the parties.
"Such a problem would be posed, for example, where the owner is held liable to a plaintiff-employee for a condition of unsea- worthiness created by the employer's negligence and there is no contract, express or implied between . . . [owner and em- ployer], or, if such contract exists, it cannot be read to lay the groundwork for an indemnification claim." ${ }^{99}$

This contention was unequivocally rejected. There can, said the court, be no action of indemnity which is not based on the violation of some contractual duty. ${ }^{100}$ Otherwise, said the court, the employer could be

95. However, the policy itself was not before the court.

96. Cf. United States F. \& G. Co. v. Virginia Engineering Co., 213 F.2d 109 (4th Cir. 1954).

97. 201 F.2d at 763.

98. 211 F.2d 16 (3d Cir. 1954).

99. Id. at 18.

100. However, this does not necessarily exclude cases where the claim is based on violation of a tort duty between the indemnitor and indemnitee. Cf. Slattery v. Marra Bros. Inc., 186 F.2d 134, 139 (2d Cir. 1951), where Judge Learned Hand noted that the Westchester Lighting Co. case, supra note 62 , might be such an instance. The shipowner's briefs in the Brown case indicate that the court was dealing with the argument that indemnity could be founded on the Washington Gas Light rule of "primary" vs. "secondary" fault. See Appellant's Petition for Rehearing, passim.

Of course, it is worth noting that the duty to exercise due care arising from contract has at times been considered as either based on tort or contract. "It is firmly established that one who is negligent in the performance of a legal duty is 
made to respond indirectly in tort to the employee for damages for which he would not be answerable under the statute, and "such a rule would be violative of Section 5 of the Act as well as of the spirit of the entire statute. . . ." 101

The Brown case was unusually emphatic in its holding that the contractual relations between the parties furnished the only basis of liability. After the opinion was announced, the appellant-shipowner was not satisfied with the judgment of reversal and filed petitions for modification of the opinion and for reargument, contending that the opinion was erroneous in limiting indemnity to a contractual basis and foreclosing the Washington Gas Light theory. The petitions were unsuccessful.

\section{Comparison of Fault and the Contractual Theory of Recovery}

In the preceding discussion, it has been demonstrated that the Act may now be viewed as eliminating the quasi-contract theory of indemnity. That theory depends on the application of equitable principles, the need for which originated in the desire to escape the hardship of the common-law prohibition against contribution, whereas the issue now becomes one of the duty between the putative indemnitor and indemnitee based on the relationship between them other than joint-tortfeasor.

But, if the recent cases in the Second Circuit are sound, it does not necessarily follow that a comparison of fault has become completely irrelevant. In Palazzolo v. Pan-Atlantic S.S. Corp. ${ }^{102}$ the grant of indemnity was based on the finding that the employer's conduct was "the primary and active cause of the accident," ${ }^{103}$ and, in Berti $v$. Compagnie de Navigation Cyprien Fabre, ${ }^{104}$ it was held that the shipowner could be entitled to indemnity, on a showing that the employer's fault was "primary." Both opinions are somewhat cryptic in their discussion of the theory of liability. In the Palazzolo case, the cause

liable for the proximate consequences of such negligence. This being true, it is immaterial whether such legal duty arises by virtue of a contract or a relationship, for in the former case, as well as the latter, the defendant is liable on the basis of tort for his failure to measure up to such duty." United States v. Bethlehem Shipbuilding Corp., 25 F.2d 157, 158 (D. Md. 1928) ; cf. The Quickstep, 9 Wall. 665, 670 (U.S. 1870); The John G. Stevens, 170 U.S. 113, 125 (1898).

101. Brown v. American-Hawaiian S.S. Co., 211 F.2d 16, 18 (3d Cir. 1954).

102. 211 F.2d 277 (2d Cir. 1954), cert. granted sub nom. Ryan Stevedoring Co., Inc. v. Pan-Atlantic S.S. Corp., 23 U.S.L. WEEK 3092 (U.S. Oct. 14, 1954).

103. For which the court cited Rich v. United States, 177 F.2d 688 (2d Cir. 1949) (see text at note 59 supra), and LoBue v. United States, 188 F.2d 800 (2d Cir. 1951).

104. 213 F.2d 397 (2d Cir. 1954). The case was remanded for trial on the issue of the shipowner's liability to the injured workman. 
of the injury was improper stowage of the cargo, which caused a roll of paper pulp to "jump" at the port of unloading. As a coincidence, it happened that both the loading at Georgetown, South Carolina, and the discharge at Brooklyn were performed by the same employer, so that any issue as to the effect of the Act arose, as it were, by accident since the fault charged to the employer related to his conduct at another time and place. As a matter of contractual obligation in connection with the loading, it seems clear that the amount of damages paid by the shipowner to the unloading employee was a foreseeable consequence of the breach by the loading employer of implied contract to perform the loading operation properly; it would be no defense to an indemnity claim against the loading stevedore that the shipowner owed a duty to provide a safe place to work to those engaged in unloading operations.

In the Berti case there was evidence on which the shipowner might be held responsible, inter alia, for a defective winch cable and for inadequacy of other equipment furnished by the ship. The court, after finding the contract ambiguous on the subject of indemnity, held that "in the absence of any contrary evidence as to the intent of the parties" the contract "established the same relationship as in Palazzolo v. PanAtlantic S.S. Corp." where the same court had referred to the employer's obligation "by implied contract to perform the work in a reasonably safe manner," ${ }^{105}$ for the breach of which the shipowner was entitled to indemnity.

Notwithstanding the difference between the Second and Third Circuits in emphasis, the opinions do not necessarily indicate conflict. Granted that the effect of the Act makes the existence of a contractual or other relational duty running from the employer to the shipowner an indispensable condition to indemnity, the questions remain: Under what circumstances will it be held that such duty has been breached and, if it has, that the breach may be held to impose a liability for indemnity? Once the duty and breach are established, the equities are apt to return as a factor in the deliberations of courts where the provisions of the contract leave room for resort to such considerations. In short, the ultimate result may be an amalgamation of the two theories of liability, in which the quasi-contract principles are imported into the areas left open by the agreements between the parties.

The application of such a rule is fairly simple in cases where the breach of duty for which the shipowner is held liable to the injured workman is a duty the entire performance of which the employer contracted to assume. 
Thus, in Lundberg v. Prudential S.S. Corp. ${ }^{106}$ in a lucid opinion, Judge Bondy held that the shipowner was entitled to indemnity. There, a painter was working on a batten inside the hold, when it became necessary to refill his paint tank. While he was descending by the lower batten boards, one of them gave way and he fell to the hold below. It was shown to be a common practice among marine painters to use battens as stepladders in order to paint the sides of the holds, a practice of which the shipowner had notice. The latter was accordingly found liable to the injured libellant on the ground that it failed to warn him the battens had not been inspected and that some of them might not be firmly lodged in their cleats, or that cleats might be missing; or, in the alternative, because of the shipowner's failure to put a stop to the use of the battens.

However, the court also found that the employer had not furnished adequate equipment, in that no ladders were provided. Since the employer had contracted with the shipowner to furnish the equipment for the job, "a necessary implication of this promise" was that the equipment would be adequate; and the breach of that promise was the "primary cause" of the injuries.

Another helpful discussion, by the same judge and leading to the same result, will be found in Valerio. $v$. American President Lines. ${ }^{107}$

In that case, the employees became infected with dermatitis by contact in unloading a cargo of cashew shell oil. The oil had leaked from the drums to the deck and cargo hooks. This cargo was known to be hazardous and one which required special precaution. It was held that the shipowner's duty to furnish a safe place to work and to warn of the dangers of handling this cargo was non-delegable, for the breach of which the shipowner was liable. The court also found, however, that the employer had contracted with the shipowner to perform the duty-i.e., to warn, to provide proper supervision, and to furnish gloves and salves; and that this breach of contract was the "primary cause" of the injuries, giving rise to the shipowner's right of full indemnity.

The use of the term "primary cause" in such cases may sound like nothing more than letting quasi-contract through the back door. Of course, what is meant is that, where the entire duty of the shipowner has been assumed by the employer, the latter's breach of contractual duty to the shipowner is the only cause which the courts will consider from the standpoint of the relation of shipowner and employer inter sese; and Judge Bondy's opinions are especially helpful because they 
focus the discussion on that relation. They do not discuss the problem of causation, simply because under the facts it was no problem at all.

Yet there are other cases in which even a resort to pure contract theory at the outset will lead ultimately to a difficult question of causation, for, if the shipowner is chargeable with something more than a breach of duty which had been entirely assumed by the employer, the problem will arise as to whether the employer's breach, as between themselves, is the proximate cause of the loss. In this type of case, the conduct of the shipowner may have a crucial bearing.

Two English cases illustrate the causation approach. Mowbray v. Merryweather ${ }^{108}$ arose on a successful claim by the employer against the shipowner to recover indemnity for damages paid by the employer to an employee for injuries caused by a defective chain supplied by the vessel. The court held that the employer's liability was the natural consequence of the shipowner's breach of implied warranty of the chain, and such as might reasonably be supposed to have been contemplated by the parties when the contract was made. Such damages, said the court, were not so remote as to be adjudged beyond their contemplation, and, although the employer concededly owed a duty to the employee to inspect the chain before allowing it to be used, no such duty was owed by the employer to the shipowner.

Nor was the approach confined to cases of breach of implied warranty. In The Kate, ${ }^{109}$ the suit was on a covenant by a lessor of a quay to keep neighboring river berths in good condition. The lessee demanded indemnity for damages it was compelled to pay to the owner of a vessel which it had permitted to be moved to a foul berth. The lessor defended on the ground that the damage was caused by the negligence of lessee itself in permitting the movement and failing to give warning. While such negligence was assumed by the court, it rejected the argument, and on the authority of Mowbray v. Merryweather held that there was no distinction between a warranty of fitness as of a given time and a covenant to keep in repair. In either case, said the court, the question is whether the damage sustained is the natural consequence of the breach of contract, notwithstanding some independent negligence on the part of the indemnitee.

It should be noted that in neither case was it suggested that, regardless of the conduct of the plaintiff-indemnitee, the defendant-indemnitor must pay. On the contrary, in both cases the court emphasized that the indemnitee had relied on the supposed performance of the contract and indicated that a different result would follow if the

108. [1895] 2 Q.B. 640 (C.A.).

109. [1935] P. 100. 
breach were known to the indemnitee at the time of the act or omission on which the charge of negligence against the indemnitee was based.110

That is to say, it does not follow that the parties did not contemplate that the promisor's responsibility extended to damages which the promisee could have avoided by taking precautions against a known danger. Likewise, in the Matthews case, where the court said no promise by the employer could be implied not to use the shipowner's rope for the very purpose for which it was furnished, ${ }^{111}$ a showing that the employer actually knew of the defect would at least raise a new issue, and this whether the question is posed in simple terms of implied promise, or causal connection to the breach.

These English cases, it is submitted, illustrate the proposition that the fault of both parties may be relevant to contractual indemnity insofar as such fault has a bearing on the vital question of breach of duties inter sese and causation related to such breach.

\section{Some Practical Considerations}

At this stage of development of the law, it seems likely that the relational basis of indemnity is on its way to acceptance. And, if this is so, it is suggested that the opinions of the courts will have a salutary effect upon future transactions if they concentrate the attention of the litigants where it belongs i.e., the parties should be plainly informed of the hazards of incomplete draftsmanship of contractual provisions defining the duties assumed by the employer. If, for instance, the parties intend that the employer shall assume the duty of making and keeping the vessel seaworthy, at least with regard to the parts and equipment to be used by his employees, and that this obligation shall extend no less to the appliances furnished by the shipowner than to those brought on board by the employer, the contract should say so; and, if they have not, it should at least be arguable that they intended the contrary by their omission.

As for express indemnity clauses, it surely requires no argument to establish that they merit new scrutiny in the light of recent developments in this field, and that they should be drawn so as to make clear those areas of responsibility which are to be unaffected by the contract relationship, as well as those which are assumed by the employer.

110. In the Berti case, where liability might be imposed on the employer for a defective condition of equipment furnished by the shipowner, the court noted that the employer was aware of the defective condition. Berti v. Compagnie de Navigation Cyprien Fabre, 213 F.2d 397, 401 (2d Cir. 1954). 1950).

111. American Mut. Liab. Ins. Co. v. Matthews, 182 F.2d 322, 323-24 (2d Cir. 
From a pragmatic standpoint, the important practical consideration involved is that the cases in this field almost always arise in situations covered by insurance. Since the arrangements between the parties contemplate insurance of their separate risks, the problem of draftsmanship is in essence the problem of mapping out their respective exposures.

Under present policy forms, it would seem that the necessary coverage should be provided by special riders to insurance contracts. ${ }^{112}$

In the ordinary case, the employer has in force a standard workmen's compensation policy which insures him against "loss by reason of the liability imposed upon him by law for damages on account of such injuries" to its employees. LoBue v. United States ${ }^{113}$ dealt with such a policy, which bore the standard New York endorsement, paragraph 10 of which specifically covers

"liability imposed upon this Employer by reason of a suit or claim brought against him by another to recover the amount of damages obtained from such other by an employee of the Employer for injuries sustained by such employee arising out of and in the course of his employment."

However, paragraph 11 of the same endorsement stipulated that such coverage was expressly "limited to the liability imposed by law upon this Employer for negligence but specifically exclude[s] any liability assumed by this Employer under any contract. . . ."

The district court found that the injuries were caused "primarily" by the negligence of the shipowner, and "secondarily" by that of the employer, and therefore held the employer not liable to indemnify the shipowner. The appeal turned on whether the policy covered the indemnity claim, inasmuch as the court construed the express indemnity clause in the contract as a promise of indemnity limited to such claims as were included within the coverage of the policy. The Circuit Court noted that paragraph 10 of the endorsement must have contemplated claims for contribution, but that was not the question, and the effect of paragraph 11 was "plainly to preclude any recovery here based upon a contractual duty assumed by [the employer] . . . to a third party. In other words, unless a third party could recover from [the employer] . . . in the absence of contract, there is no insurance coverage. . . ."114

112. See Potamkin and Plotka, supra note 52 , at 365 .

113. 188 F.2d 800 (2d Cir. 1951), followed in Palardy v. United States, 102 F. Supp. 534 (E.D. Pa. 1952).

114. LoBue v. United States, 188 F.2d 800, 803 (2d Cir. 1951). 
We have already seen that any claim for indemnity which is not based on a duty, either in tort or in contract, between shipowner and employer, must give way before the effect of Section 5 of the Act. If, therefore, the duty is based on the contractual relationship, LoBue stands for the proposition that the policy does not cover. As for the standard form of manufacturers' and contractors' schedule policy, again the coverage is limited to "all sums which the insured shall become obligated to pay by reason of the liability imposed upon him by law. . " and the same limitation would seem applicable in the absence of special riders or express policy declarations. ${ }^{115}$ Under the circumstances, not only a review of the contract provisions, but a new look at the forms of policies is in order, and, it may be assumed, is actually taking place.

\section{Summary AND Conclusions}

It yet remains to be seen whether the Supreme Court will place its stamp of approval on the doctrines which have been worked out by the Second and Third Circuits. Until the Palazzolo ${ }^{116}$ case is decided, those doctrines must continue to be regarded as controversial; but, whether affirmed or reversed, that case provides an opportunity to finalize the basic rules thus far developed, resulting at least in the advantage of that certainty which the various interests in this field so urgently require. A well-considered and carefully-reasoned opinion could bring to an end the first stage of the development of this branch of the law.

But it does not follow that, in such case, all difficulties would vanish. Assuming that the rules of relational indemnity are affirmed, their application will continue to present many new issues. Suppose, for example, that an employer who engages himself to perform certain work, has by implication agreed to do it carefully and properly, in that he must adopt every reasonable precaution against loss to the shipowner by damage suits, and that his contractual undertaking extends as well to suits by his employees as to suits by anyone else: the question of causation is bound to arise in any case where any negligence is shown on the part of the shipowner. Again, there may be an issue as to the extent to which damages are within the contemplation of the parties under the circumstances. Furthermore, a showing that the practice which caused the accident was adopted by the employer for the benefit, or with the acquiescence, of the shipowner, would surely be entitled to weight, at least as a matter of contractual interpretation.

115. The policy excludes liability assumed by the assured under contract. 116. See note 51 supra. 
These are only a few samples of the numerous questions which may be anticipated.

As such issues arise for solution, the emergent decisions will form a new branch of the law of contract. They will be channelled, of course, by the special factors derived from the application of the Statute, and perhaps ultimately come out as a refinement of contractual indemnity without any precise parallel elsewhere. Yet, the restriction to a contractual basis should not eliminate all resort to the large number of cases already available in the field of quasi-contract; as a source of analogy the latter will inevitably influence the decisions. However that may be, the finished process should illustrate once again the marvelous workings of that laboratory which we call the common law. 